\title{
MILHO TRANSGÊNICO (BT): EFEITO SOBRE PRAGAS ALVO E NÃO ALVO
}

ISSUE DOI: $10.3738 /$ nucleus.v0i0.903

\begin{abstract}
RESUMO: Um dos principais fatores que comprometem o rendimento e a qualidade da produção de milho é a incidência de pragas. Dentre estas, destacam-se a lagarta-do-cartucho, Spodoptera frugiperda, a lagarta-da-espiga, Helicoverpa zea e a broca-da-cana-de-açúcar, Diatraea saccharalis. Com o advento da biotecnologia, foi desenvolvida uma nova tática de controle de pragas, que consiste nas plantas geneticamente modificadas resistentes a insetos, os chamados transgênicos. Em 2008 começaram os primeiros plantios comerciais de milho Bt no Brasil e a cada ano são liberadas comercialmente novas tecnologias. Assim, é importante a comparação destas tecnologias com os híbridos convencionais submetidos a pulverizações com inseticidas para controle das pragas além de seus efeitos em pragas não alvo como o percevejo barriga-verde, Dichelops melacanthus.
\end{abstract}

Palavras-chave: Zea mays. Spodoptera frugiperda. Diatraea saccharalis, Dichelops melacanthus, Bacillus thuringiensis. Milho convencional. Inseticida.

\section{TRANSGENIC MAIZE: EFFECT ON TARGET AND NON-TARGET PESTS}

SUMMARY: One of the main factors that impact the yield and quality of corn production is the incidence of pests. Among these, Spodoptera frugiperda, Helicoverpa zea and Diatraea saccharalis are the most important. With the advent of biotechnology, was developed a new tactic pest control, consisting of genetically modified plants resistant to insects, called transgenic. The first commercial planting of Bt maize in Brazil began in 2008 and every year new technologies are released commercially. Thus, it is important to compare these technologies with conventional hybrids subjected to spraying with insecticides for pest control in addition to its effects on non-target pests such as Dichelops melacanthus.

Keywords: Zea mays. Spodoptera frugiperda. Diatraea saccharalis. Dichelops melacanthus. Bacillus thuringiensis. Conventional maize. Insecticide.

\section{INTRODUÇÃO}

Com base na importância dos prejuízos ocasionados por lepidópteros, os primeiros eventos expressando as toxinas do $\mathrm{Bt}$ em milho visaram, principalmente, ao controle da lagarta-européia-do-milho, Ostrinia nubilalis (Hubner) (Lepidoptera: Crambidae). Posteriormente, houve a incorporação de novas toxinas abrindo a possibilidade para o uso no controle de várias outras espécies (WAQUIL, 2007).

No Brasil, destacam-se como lepidópteros pragas, a lagarta-do-cartucho, Spodoptera frugiperda (Smith), a lagarta-da-espiga, Helicoverpa zea (Bod.) e a broca-da-cana-de-açúcar, Diatraea saccharalis (Fab.) (GALLO et al., 2002).

\footnotetext{
${ }^{1}$ Pesquisador Científico, APTA, Polo Regional Centro Norte, Pindorama, SP. E-mail: michelotto@apta.sp.gov.br;

2 Doutorando, Programa de Pós-graduação em Entomologia Agrícola, Departamento de Fitossanidade, FCAV/UNESP, Jaboticabal, SP. E-mail: jacob_netto@hotmail.com;

${ }^{3}$ Pesquisador Científico, APTA, Polo Regional Noroeste Paulista, Votuporanga, SP. E-mail: freitas@apta.sp.gov.br

${ }^{4}$ Pesquisador Científico, Programa Milho IAC/APTA, Centro de Grãos e Fibras, IAC, Campinas, SP. E-mail: aildson@apta.sp.gov.br

${ }^{5}$ Professor Titular, Departamento de Fitossanidade, FCAV/UNESP, Jaboticabal, SP. E-mail: acbusoli@ fcav.unesp.br
} 
Em função dos prejuízos ocasionados principalmente pela lagarta-do-cartucho foi desenvolvido o milho geneticamente modificado ou milho $B t$, ou seja, foram obtidos híbridos contendo um ou mais gene do Bacillus thuringiensis o qual tem efeito inseticida sobre vários lepidópteros pragas. B. thuringiensis $(B t)$ é uma bactéria comum que produz proteínas que são tóxicas a certos lepidópteros. A transferência de genes exógenos para plantas cultivadas à partir das técnicas de engenharia genética pode ser considerada um dos avanços mais significativos dentro das ciências biológicas nos últimos anos (WAQUIL, 2007).

$\mathrm{O} B t$ produz várias proteínas inseticidas sendo as proteínas cristais as mais eficientes, responsáveis pela ação inseticida da bactéria, sendo composto por uma ou mais proteínas (proteínas $B t$ ) que inativam as células do intestino do inseto. As proteínas cristais são dissolvidas no suco gástrico do lúmen do intestino do inseto e pela ação das proteases intestinais do inseto são transformadas em partículas tóxicas que em contato com células do epitélio intestinal incham-na e estouram-nas causando a morte do inseto (LYNCH et al., 1999).

Uma das principais e importantes características das proteínas inseticidas CRY é sua alta especificidade em relação às espécies-alvo de insetos afetados, devido a uma co-evolução de proteínas receptoras de superfície no intestino médio (mesentero) dos insetos-alvo sensíveis; esses receptores ligamse de forma específica às $\alpha$-endotoxinas, modificando sua conformação e causando vazamento de íons e dano osmótico das células, o que conduz, consequentemente, à desintegração do mesentero e a morte do inseto. Esse efeito tóxico seletivo não se estende a outros organismos que não tenham tais receptores compatíveis, tornando as inertes a seres humanos, peixes, animais selvagens e a outros insetos benéficos (inimigos naturais), que podem auxiliar no controle biológico da praga-alvo, além de outras (JIMENEZJUAREZ et al., 2007).

Essa tecnologia está se tornando a principal ferramenta de controle das pragas na cultura do milho, como mostra a Tabela 1. No estado de São Paulo, a adoção de algum evento para controle de insetos chega a 86,4\%, segundo estimativas da CÉLERES (2013). Entretanto, para que seja uma opção sustentável é necessário atentar para o impacto dessa tecnologia no ecossistema, avaliando sua real eficiência, seus efeitos sobre os inimigos naturais e no desenvolvimento de populações de insetos resistentes a essas toxinas.

Tabela 1. Estimativa de adoção da biotecnologia na cultura do milho (total da $1^{\mathrm{a}}$ e $2^{\mathrm{a}}$ safras) no Brasil, safra 2012/13.

\begin{tabular}{lccccccc}
\hline \multirow{2}{*}{ Unidade Federativa } & \multirow{2}{*}{$\begin{array}{c}\text { Área } \\
\text { (milhão ha) }\end{array}$} & \multirow{2}{*}{$\begin{array}{c}\text { Produtividade } \\
\text { (t/ha) }\end{array}$} & \multirow{2}{*}{$\begin{array}{c}\text { Produção } \\
\text { (milhão t) }\end{array}$} & \multicolumn{4}{c}{ Adoção (\% area total) } \\
\hline Bahia & 0,86 & 2,72 & 2,33 & $27,5 \%$ & $5,3 \%$ & $21,7 \%$ & $54,5 \%$ \\
São Paulo & 0,93 & 5,42 & 5,04 & $44,4 \%$ & $8,4 \%$ & $42,0 \%$ & $94,8 \%$ \\
Goiás & 0,97 & 6,53 & 6,35 & $40,6 \%$ & $8,2 \%$ & $43,0 \%$ & $91,8 \%$ \\
Rio Grande do Sul & 1,08 & 4,33 & 4,68 & $45,6 \%$ & $5,1 \%$ & $37,9 \%$ & $88,6 \%$ \\
Minas Gerais & 1,09 & 6,42 & 7,03 & $54,4 \%$ & $6,5 \%$ & $29,7 \%$ & $90,5 \%$ \\
Mato Grosso do Sul & 1,27 & 4,11 & 5,22 & $36,6 \%$ & $9,0 \%$ & $42,5 \%$ & $88,1 \%$ \\
Paranán & 3,00 & 6,07 & 18,23 & $39,8 \%$ & $7,8 \%$ & $43,3 \%$ & $90,9 \%$ \\
Mato Grosso & 3,24 & 5,65 & 18,32 & $37,8 \%$ & $9,8 \%$ & $43,7 \%$ & $91,3 \%$ \\
\hline
\end{tabular}

Fonte: Adaptado de CÉLERES, 2013. 


\section{EFEITO DAS TECNOLOGIAS BT NO CONTROLE DA LAGARTA-DO-CARTUCHO}

A Apta Regional e o Instituto Agronômico de Campinas, com o apoio da FAPESP, realizaram pesquisas para avaliar a eficiência dos híbridos comerciais de milho $B t$ contendo as diferentes tecnologias no controle dos lepidópteros pragas no Estado de São Paulo, conforme Tabela 2 (GATTI et al., 2012; PIROTTA et al., 2012; MICHELOTTO et al., 2012).

A lagarta-do-cartucho, além de polífaga, ataca as plantas de milho em diferentes estádios de desenvolvimento, deixando a planta hospedeira suscetível por longo período de tempo. Após a eclosão (Figura 1), as lagartas iniciam sua alimentação raspando as folhas jovens do milho. Com o crescimento das lagartas, ocorre o aumento do consumo foliar chegando a destruir o cartucho das plantas (Figura 2).

Para avaliação desta lagarta, seus danos foram avaliados através de escala de notas de danos visuais adaptada de DAVIS et al. (1992), que varia de 0 (sem danos) a 9 (cartucho totalmente destruído) e observou-se que os materiais $B t$ 's, pulverizados ou não são menos atacados (Figura 3).

Figura 1. Lagartas de S. frugiperda recém eclodidas.

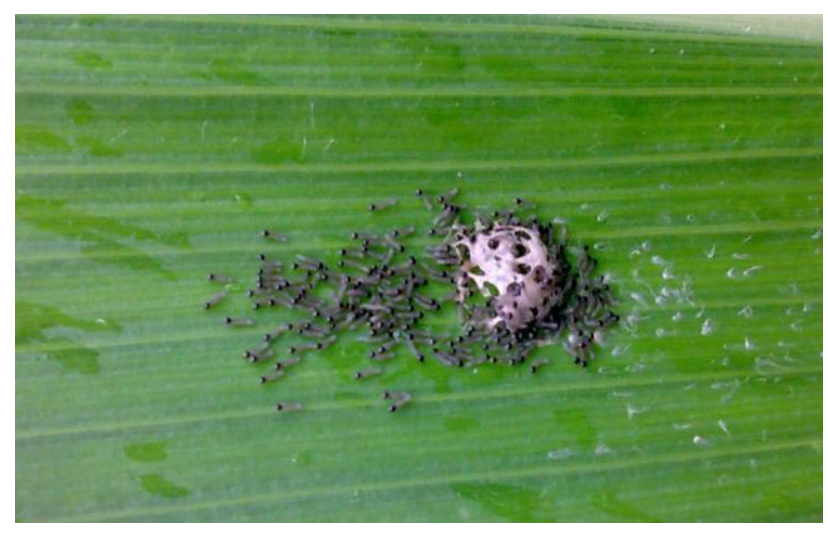

Figura 2. Plantas de milho convencional não pulverizado atacadas pela lagarta do cartucho (esquerda) e detalhe do cartucho destruído (direita).
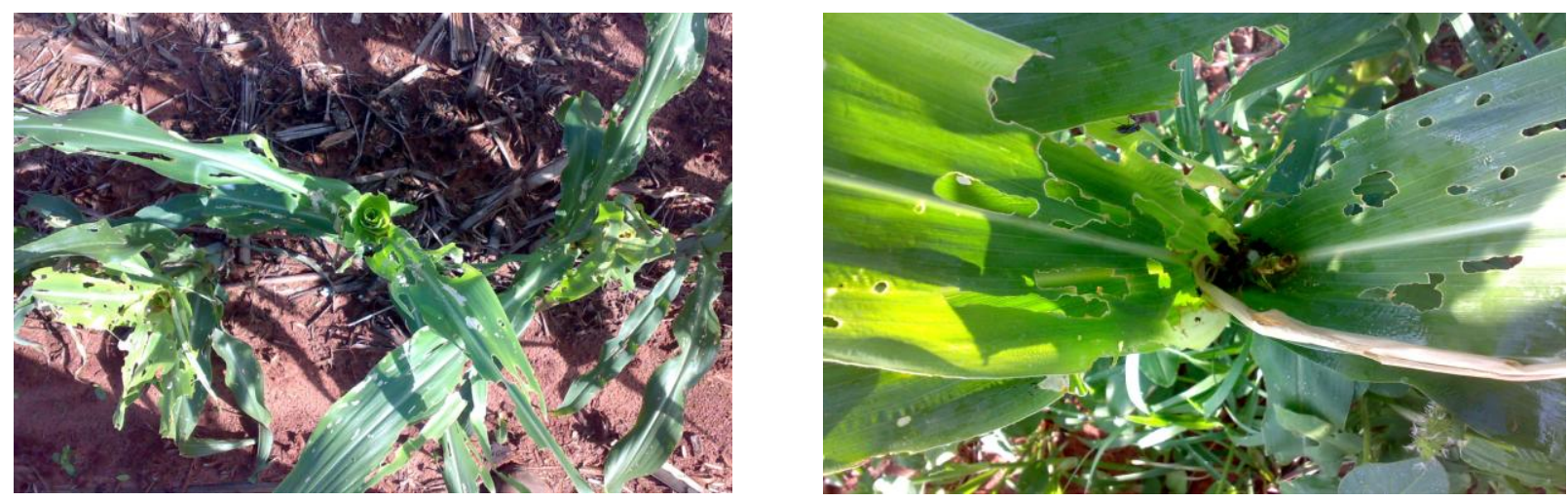
Figura 3. Plantas de milho transgênico (esquerda) sem sintomas de ataque da lagarta-do-cartucho e convencional (direita) com sintomas.

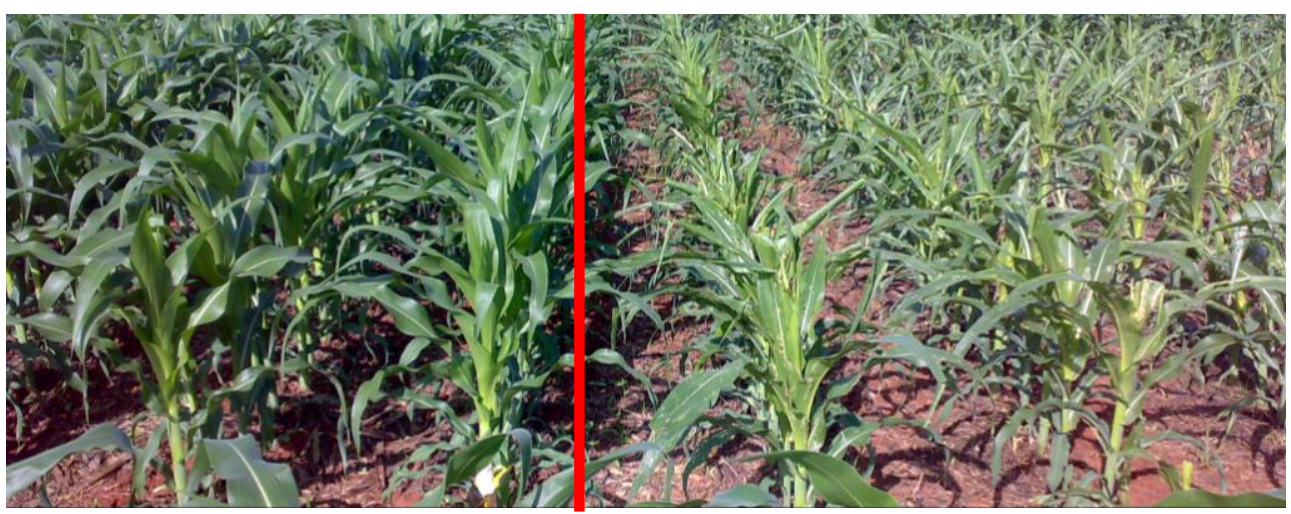

Com relação à lagarta-do-cartucho, observou-se em Pindorama, que os híbridos $B t$ 's, pulverizados ou não com inseticidas diferem com relação ao ataque da lagarta-do-cartucho. Os híbridos contendo as tecnologias com apenas uma proteína (Yieldgard, Total Liberty e Herculex) apresentaram as maiores percentagens de plantas com sintomas de ataque da lagarta ao passo que as tecnologias mais recentes, contendo uma ou mais proteínas foram menos atacadas (Figura 3), o mesmo acontecendo quando foram atribuídas notas de sintomas variando de 0 (sem sintomas de ataque) a 9 (cartucho totalmente destruídos), conforme Figura 5.

Tabela 2. Tecnologias de milho Bt avaliados até safra 2011/12.

\begin{tabular}{lllc}
\hline \multicolumn{1}{c}{ Evento } & \multicolumn{1}{c}{ Marca } & \multicolumn{1}{c}{ Toxina } & $\begin{array}{c}\text { Sigla presente } \\
\text { nos Híbridos }\end{array}$ \\
\hline MON810 & Yieldgard $\AA$ & Cry 1Ab & YG ou Y \\
MON89034 & Yieldgard VTPRO $\otimes$ & $\begin{array}{l}\text { Cry 1A105 }(1 \mathrm{Ab}, 1 \mathrm{Ac}, 1 \mathrm{~F})+ \\
\text { Cry2Ab2 }\end{array}$ & VTpro \\
TC1 507 & Herculex ${ }^{\circledR}$ & Cry 1F & HX ou H \\
SYN - & Total Liberty ${ }^{\circledR}$ & Cry 1Ab & TL \\
BT011 & & VIP3Aa20 & Viptera \\
MIR 162 & Viptera ${ }^{8}$ & & \\
\hline
\end{tabular}

Figura 4. Porcentagem de plantas com algum sintoma de ataque da lagarta-do-cartucho em híbridos de milho com diferentes tecnologias $B t$, pulverizados ou não com inseticida. Pindorama, SP.

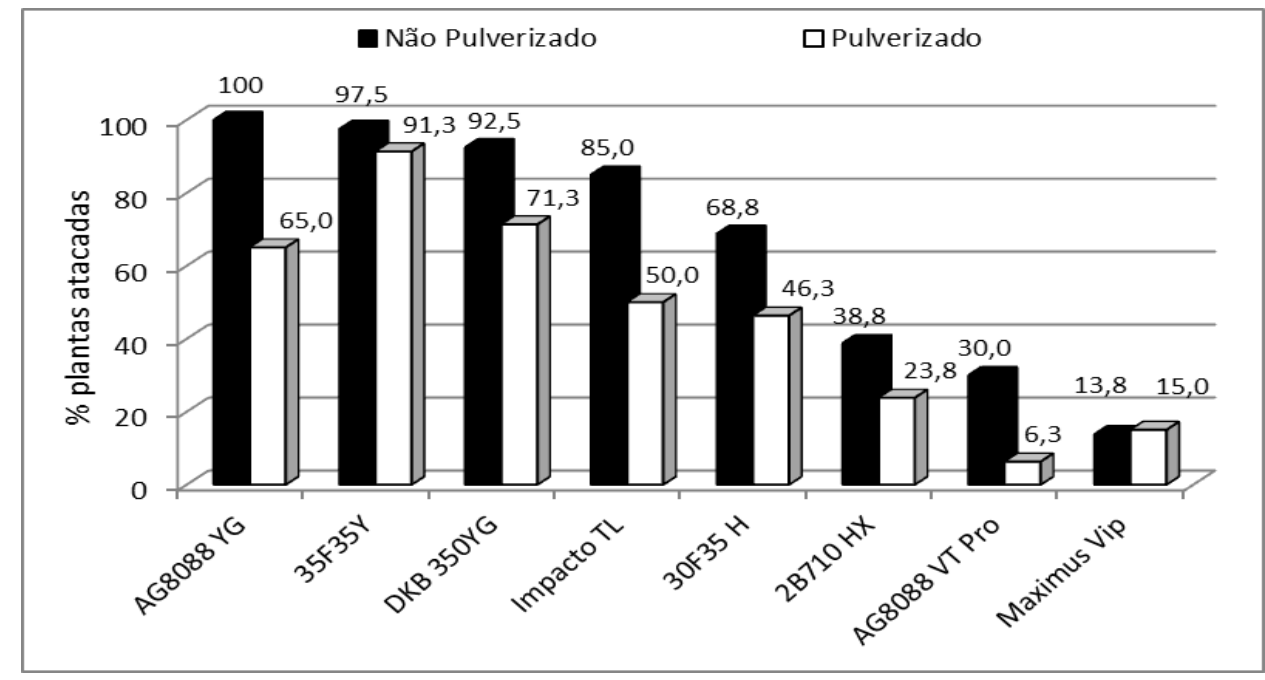

Nucleus, Edição Especial, 2013 
Figura 5. Notas de sintomas visuais de ataque da lagarta-do-cartucho em híbridos de milho de diferentes tecnologias $B t$, pulverizados ou não com inseticida. Pindorama, SP.

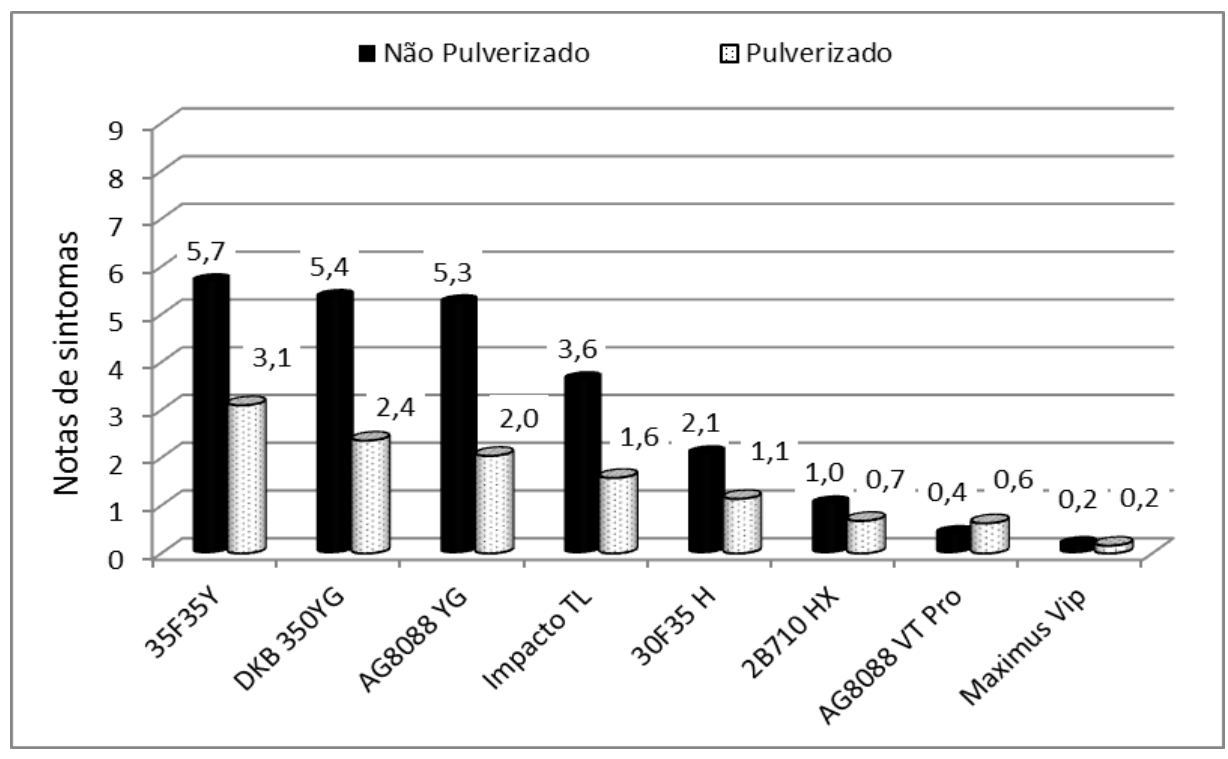

Já em outra localidade do estado de São Paulo, mais especificamente em Votuporanga, a diferença entre as tecnologias não foi muito evidente (Figura 6), possivelmente porque a ocorrência de adultos da lagarta do cartucho foi menor ou houve maior número de inimigos naturais na área que não deixaram a população de lagartas aumentarem a ponto de causar danos nas plantas.

Figura 6. Notas de sintomas visuais de ataque da lagarta-do-cartucho em híbridos de milho de diferentes tecnologias $B t$, pulverizados ou não com inseticida. Votuporanga, SP

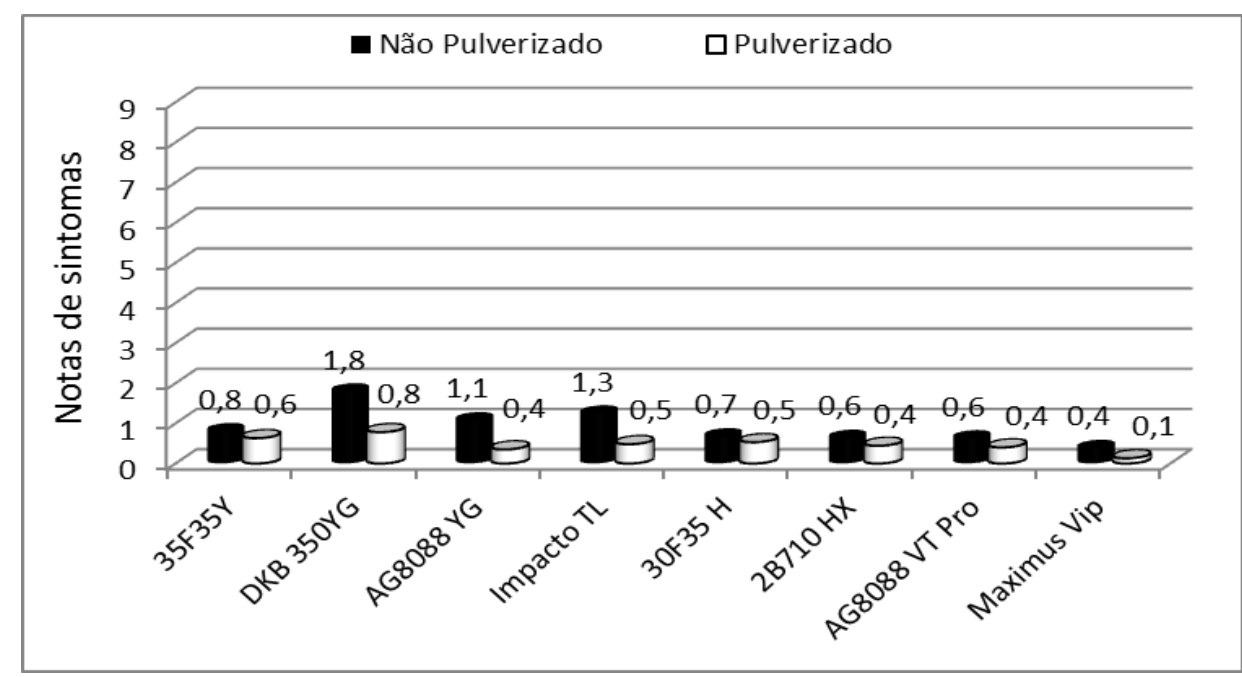

\section{EFEITO DAS TECNOLOGIAS BT NO CONTROLE DA BROCA-DA-CANA}

Esta praga tem aumentado de importância para a cultura do milho, sorgo e arroz, em diversas regiões do país. Além disso, em função das áreas de milho no Estado de São Paulo estar vizinhas aos canaviais tem aumentado sua importância principalmente quando o controle desta broca não é realizado satisfatoriamente com a liberação do parasitoide Cotesia flavipes (Cameron) (Hymenoptera: Braconidae). 
No início do desenvolvimento das plantas, as larvas atacam o cartucho, alimentando-se do tecido jovem em desenvolvimento podendo danificar o broto terminal, provocando sua morte. Em plantas mais desenvolvidas, as larvas penetram no colmo e fazem galerias (Figura 7). Larvas mais desenvolvidas, ao intensificarem o dano, enfraquecem as plantas, que ficam propensas ao quebramento.

Ao atacarem o interior do colmo da planta, as larvas ocasionam danos que podem acarretar perdas entre 10 e $50 \%$ nos rendimentos. As maiores perdas são advindas de ataques nos entrenós mais próximos à espiga, pois produzem interferência na circulação de nutrientes elaborados pela planta, que são carreados para uma maior produção de folhas, em vez da produção de grãos.

Os resultados obtidos mostraram que os híbridos convencionais quando não pulverizados podem apresentar até $50 \%$ das plantas atacadas pela broca dependendo da região. A pulverização realizada para controle da lagarta do cartucho apresentou algum controle para a broca-da-cana, mas os híbridos Bt's apresentaram uma alta eficiência de controle independentemente da tecnologia adotada, como mostram as figuras 8 e 9 .

Figura 7. Broca-da-cana em colmo de milho convencional

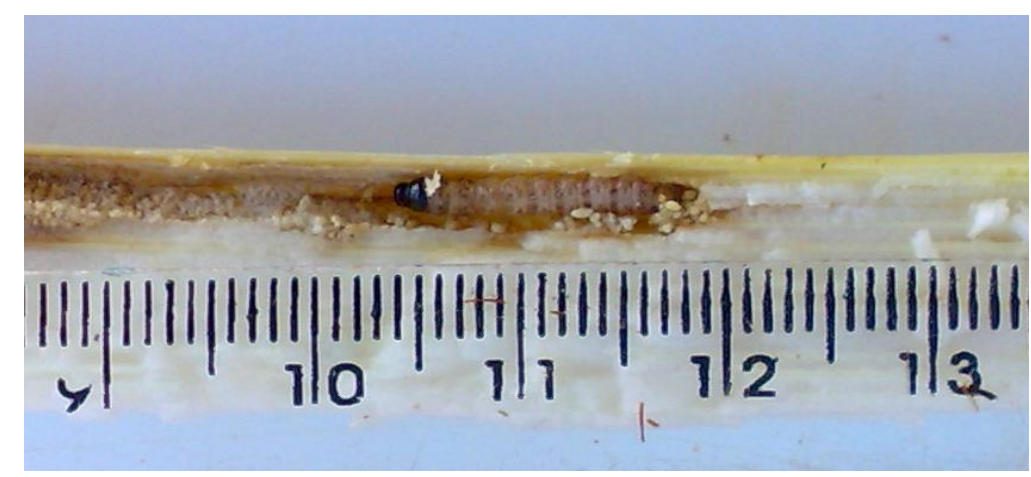

Figura 8. Colmos de híbridos convencionais atacdos pela broca-da-cana (esquerda) e colmos de híbrido transgênico sadio (direita).

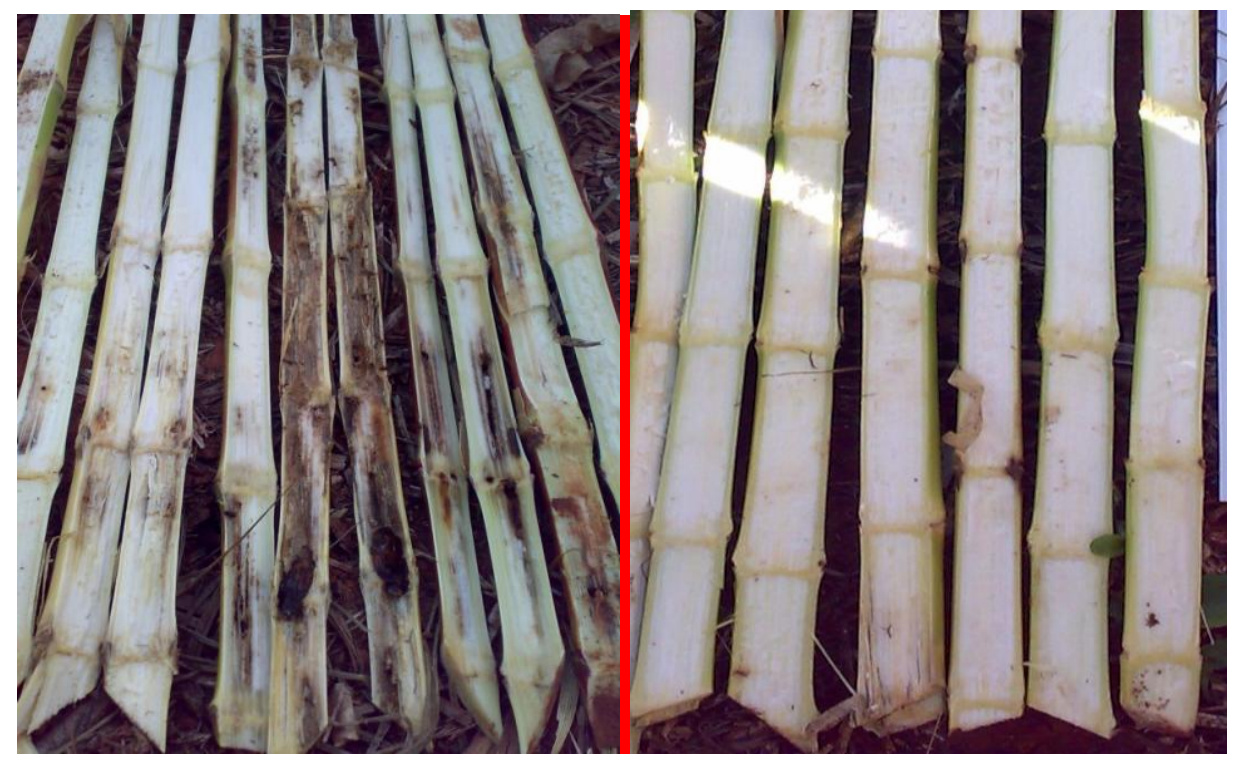


Figura 9. Percentagem de plantas atacadas pela broca-da-cana em híbridos de milho convencional e transgênico na safra de verão e safrinha, submetidos ou não à pulverização com inseticida.
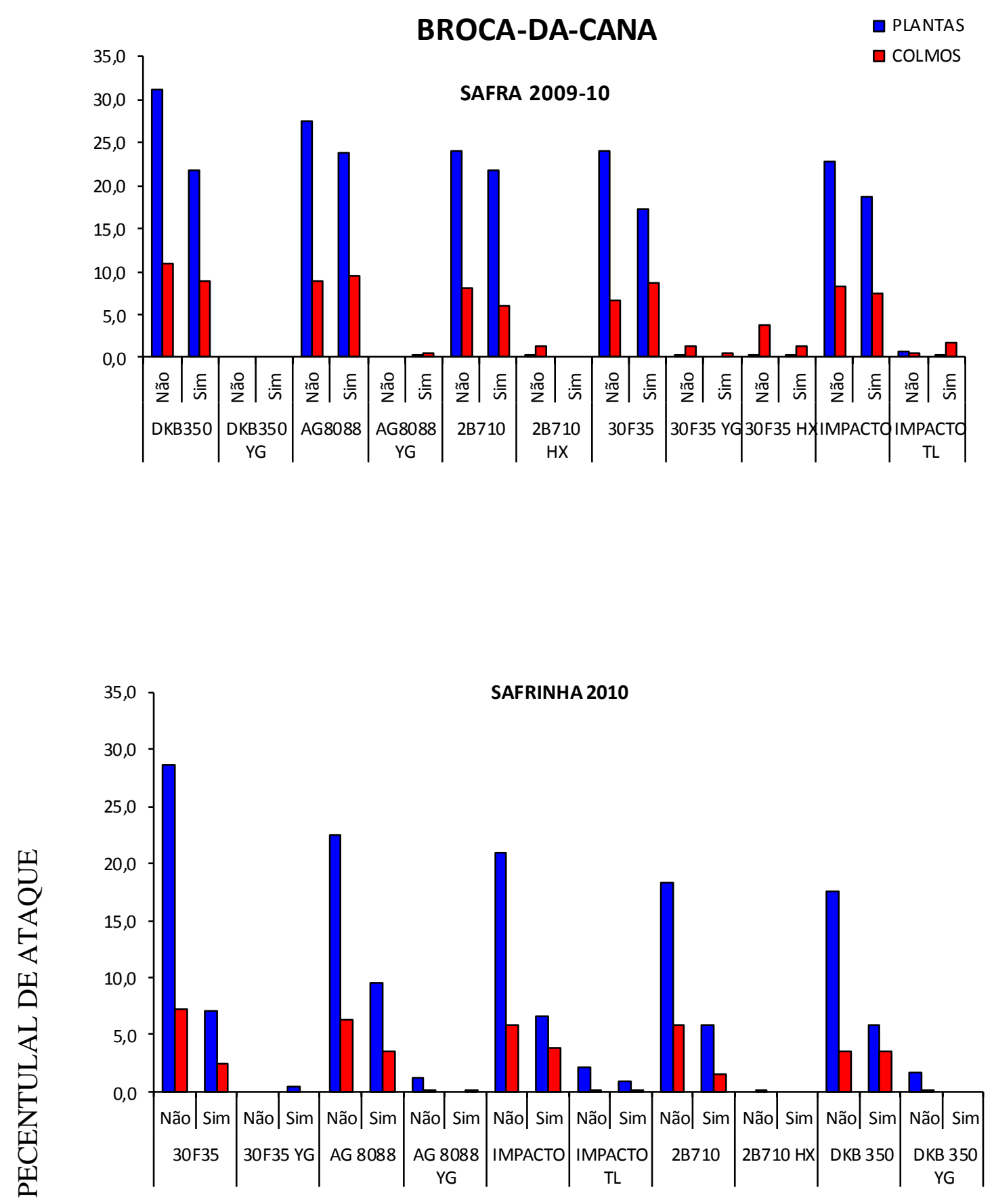

HÍBRIDOS PULVERIZADOS OU NÃO

\section{EFEITO DAS TECNOLOGIAS BT NO CONTROLE DE LAGARTAS NA ESPIGA}

A lagarta-da-espiga, também é importante pela sua ocorrência endêmica e pela dificuldade de seu controle. Além de seus danos diretos, causa danos indiretos pela abertura da espiga facilitando a entrada de outras pragas, umidade e fungos causadores de podridões. 
A mariposa coloca seus ovos nos estilos-estigmas ("cabelo do milho"). No entanto, a praga pode também colocar os ovos nas folhas de plantas ainda em estádios vegetativos de desenvolvimento. Podem ser encontrados até 13 ovos por espiga, tendo um período de incubação em torno de três dias. As larvas recém-nascidas inicialmente alimentam-se dos cabelos de milho, e dependendo da intensidade de ataque podem ocorrer grandes falhas nas espigas pela não-formação dos grãos. À medida que as larvas se desenvolvem elas caminham em direção à ponta da espiga, onde começam a alimentar-se dos grãos em formação.

Além da lagarta da espiga, a lagarta-do-cartucho também pode atacar a espiga (Figura 10) e os danos muitas vezes são confundidos. Quando a larva está presente na espiga podem-se separar facilmente as espécies através da coloração da cabeça. A lagarta-da-espiga tem a cabeça de coloração marrom bem clara enquanto a lagarta-do-cartucho apresenta a cabeça quase preta.

Figura 10. Lagarta-do-cartucho (esquerda) e lagarta-da-espiga (direita).
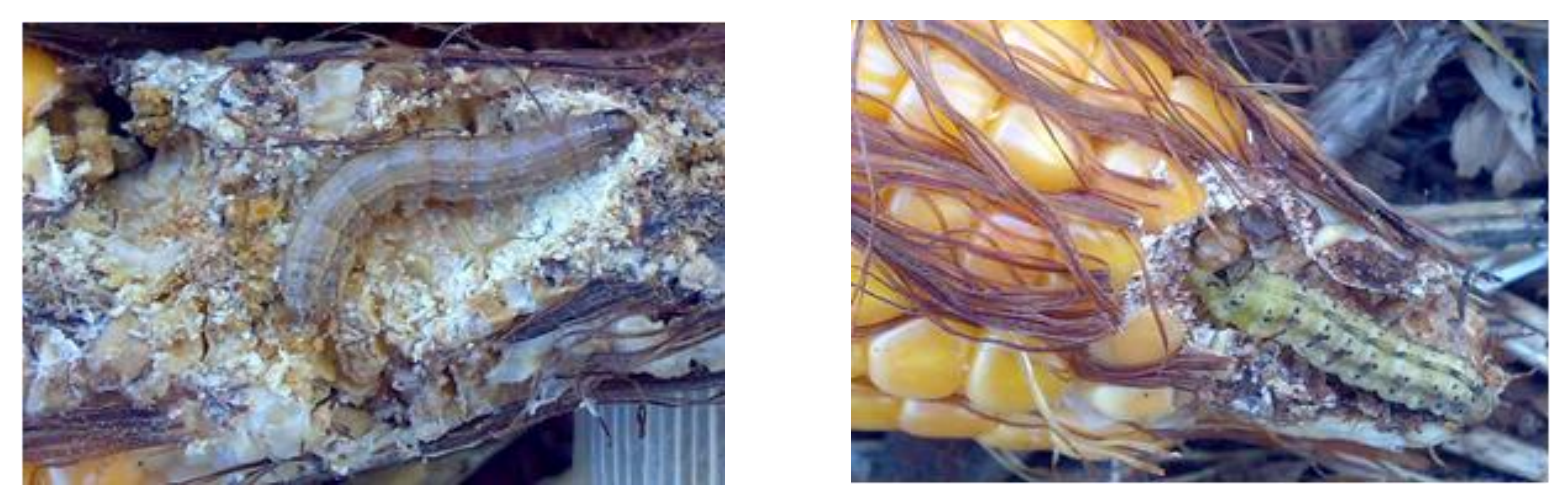

Independentemente das espécies que atacaram as espigas, observou-se quando se utilizou híbridos convencionais, pulverizados ou não, a percentagem de espigas atacadas ou as notas atribuídas aos sintomas são muito altas (Figuras 11 e 12). Já entre os híbridos Bt's somente uma tecnologia foi altamente eficiente no controle das lagartas na espiga (Figuras 12 e 13), as outras tecnologias apesar de apresentarem percentagens de espigas atacadas relativamente altas, suas notas de sintomas foram bem melhores que as notas das espigas dos híbridos convencionais.

Figura 11. Porcentagem de espigas atacadas por lagartas e notas de sintoma de ataque nas espigas de híbridos de milho convencionais. Pindorama, SP. 2011.

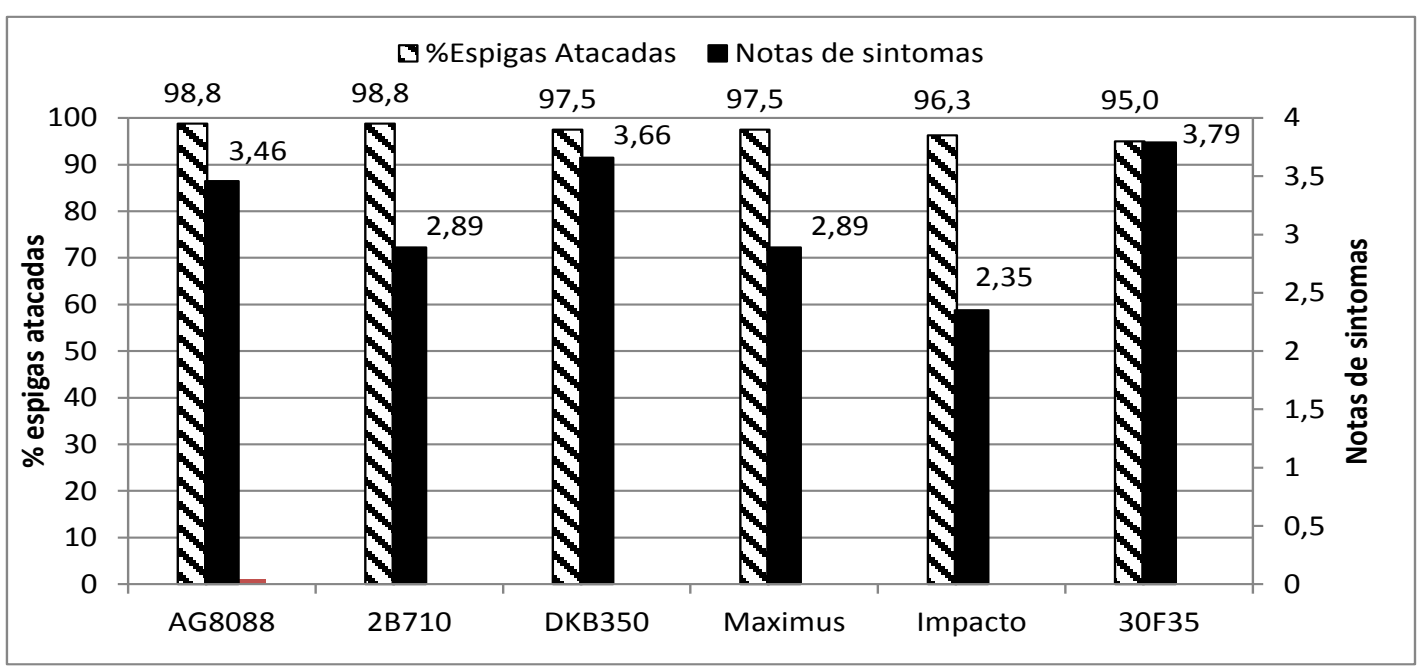

Nucleus, Edição Especial, 2013 
Figura 12. Espigas de milho convencionais com sintomas de ataque de lagartas (esquerda) e sintomas de ataque na tecnologia Viptera (direita). Pindorama, SP. 2011.
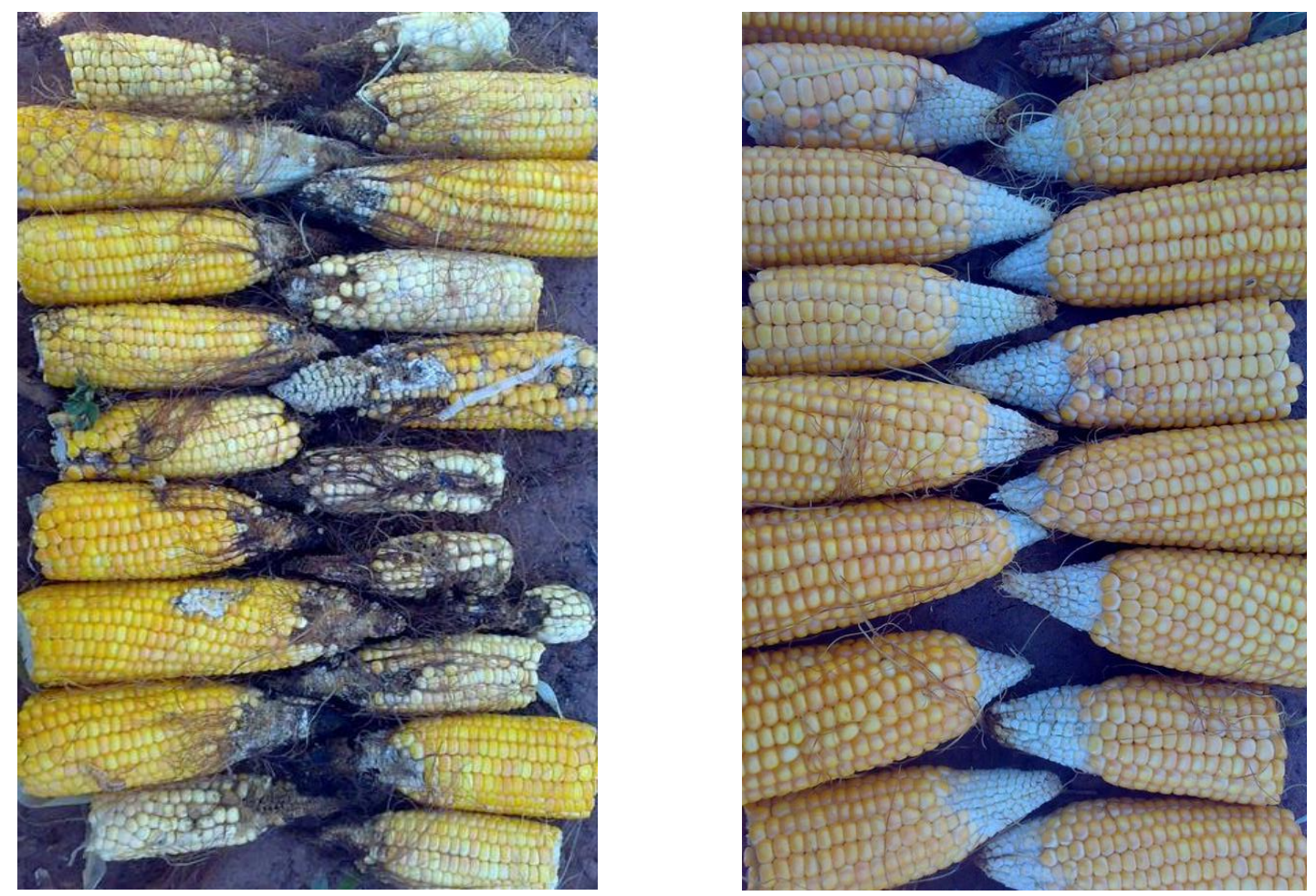

Figura 13. Porcentagem de espigas atacadas por lagartas e notas de sintoma de ataque nas espigas de híbridos de milho Bt. Pindorama, SP. 2011

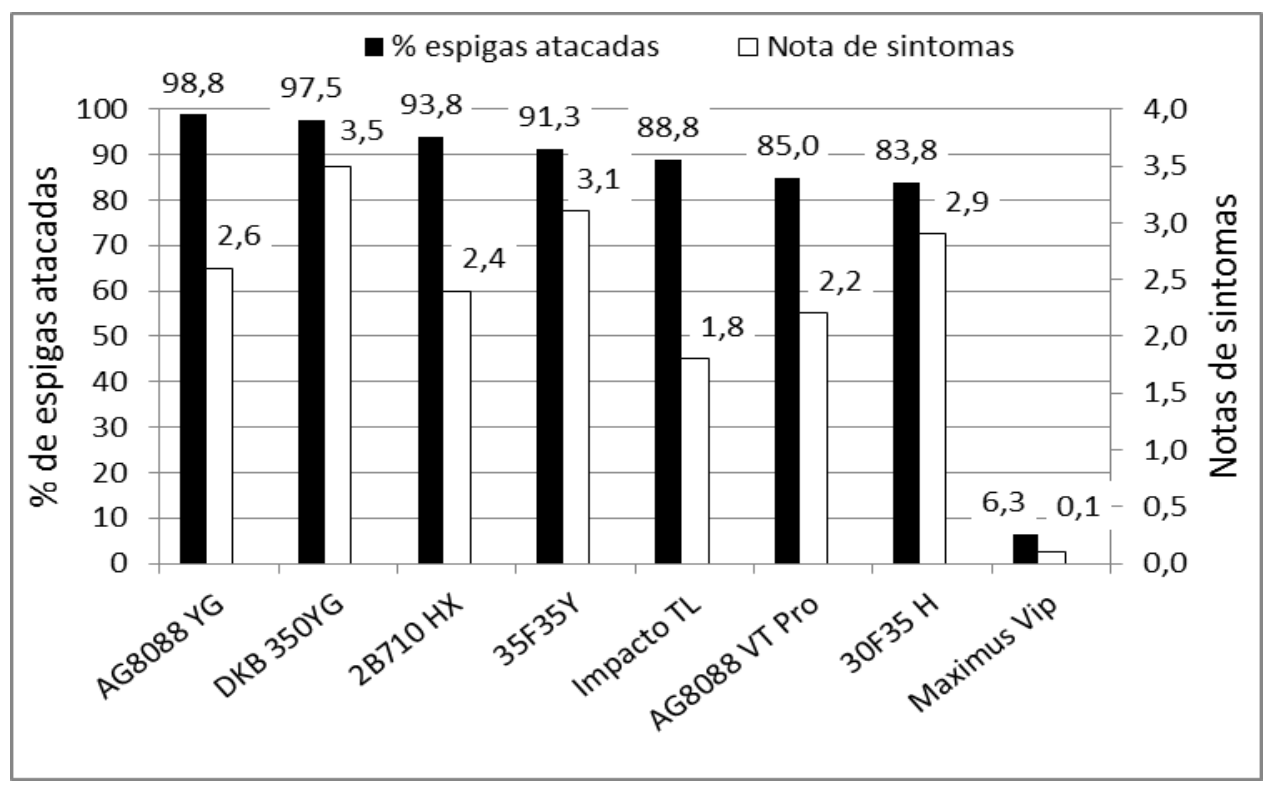




\section{EFEITO DAS TECNOLOGIAS BT NA PRODUTIVIDADE}

Com relação à produtividade, a maioria dos híbridos $B t$ 's obtiveram maiores produtividades em relação aos seus respectivos híbridos convencionais sem a aplicação de inseticida. Importante ressaltar que esta tecnologia $(B t)$ é protetora da produtividade, ou seja, seu uso não aumenta a produtividade, mas tem por finalidade proteger a planta das pragas para que elas possam expressar ao máximo seu potencial produtivo. Dessa forma, quanto maior o ataque das lagartas, maior será sua resposta em relação aos híbridos convencionais e em casos em que não ocorrer a praga, os híbridos $B t$ terão as mesmas produtividades que seus respectivos híbridos convencionais.

Importante destacar também que na safrinha o potencial produtivo é prejudicado e que o posicionamento do híbrido nas regiões mais adequadas é muito importante. De qualquer modo, foi possível verificar na safrinha de 2011 que em Pindorama, a maioria dos híbridos transgênicos produziu mais que seus respectivos híbridos convencionais pulverizados com inseticidas, com exceção do híbrido Impacto TL, que produziu praticamente igual ao convencional conforme Figura 14.

Figura 14. Produtividade $\left(\mathrm{Kg}_{\mathrm{g}} \mathrm{ha}^{-1}\right)$ de híbridos de milho convencionais pulverizados e de híbridos $B t$ não pulverizados na safrinha de 2011. Pindorama, SP.

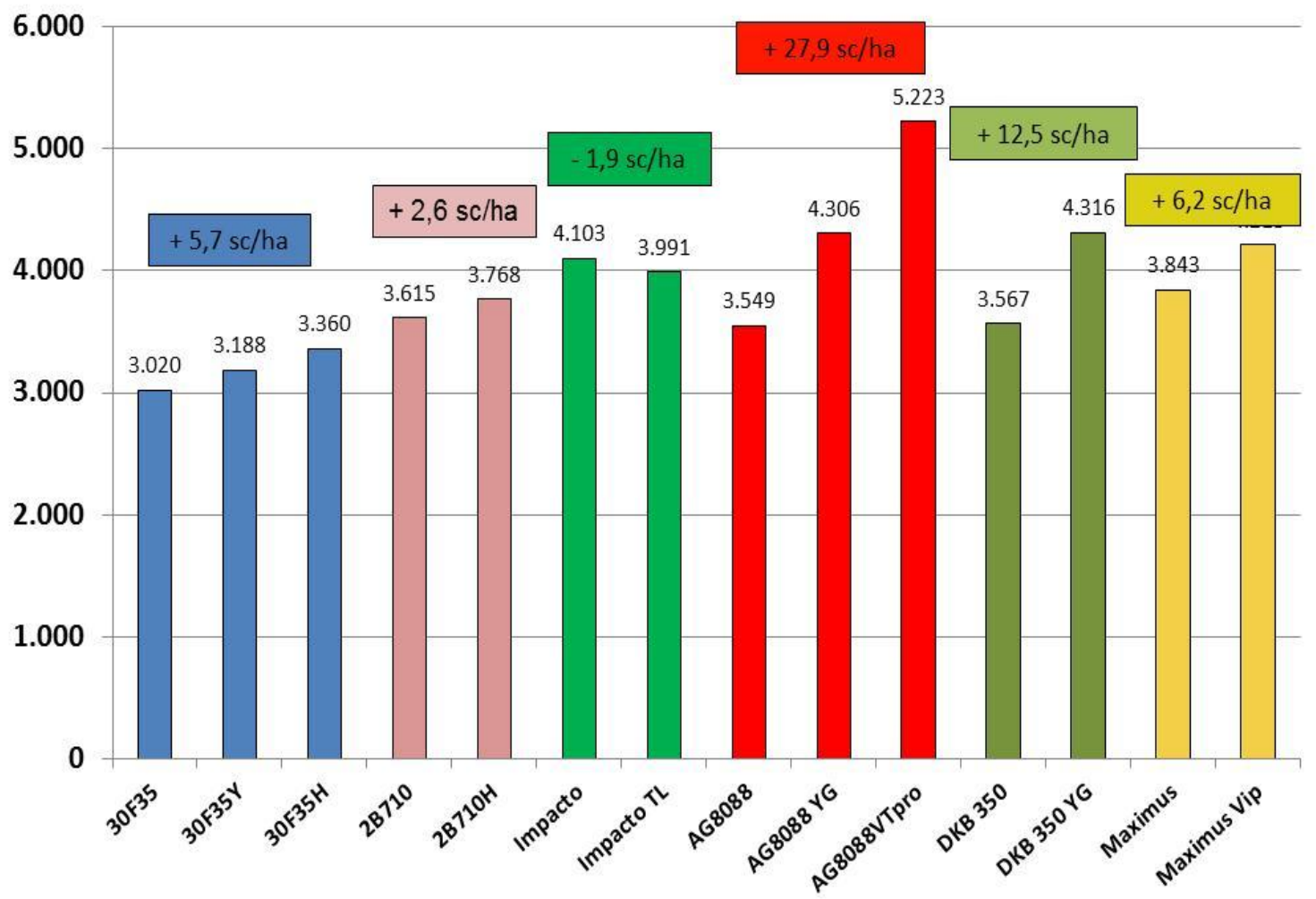

Já no verão onde as condições são mais favoráveis à cultura do milho, observou-se que os híbridos transgênicos produziram em média 13,5 sacos por hectare a mais que a média dos híbridos convencionais pulverizados com inseticidas (Figura 15).

Obviamente não podemos extrapolar estes resultados para todos os locais e situações. Mas estes dados servem para ilustrar que os híbridos transgênicos contendo diferentes tecnologias são ferramentas da qual podemos utilizá-las ou não dependendo de critérios. Podemos ainda caracterizar esta tecnologia como uma espécie de seguro contra o ataque de lagartas. 
Figura 15. Média de produtividade $\left(\mathrm{Kg} / \mathrm{ha}^{-1}\right)$ de híbridos de milho convencionais e $B t$ pulverizados ou não na safra de verão 2010/11. Pindorama, SP. * Nota média de sintomas visuais de ataque da lagarta-do-cartucho.

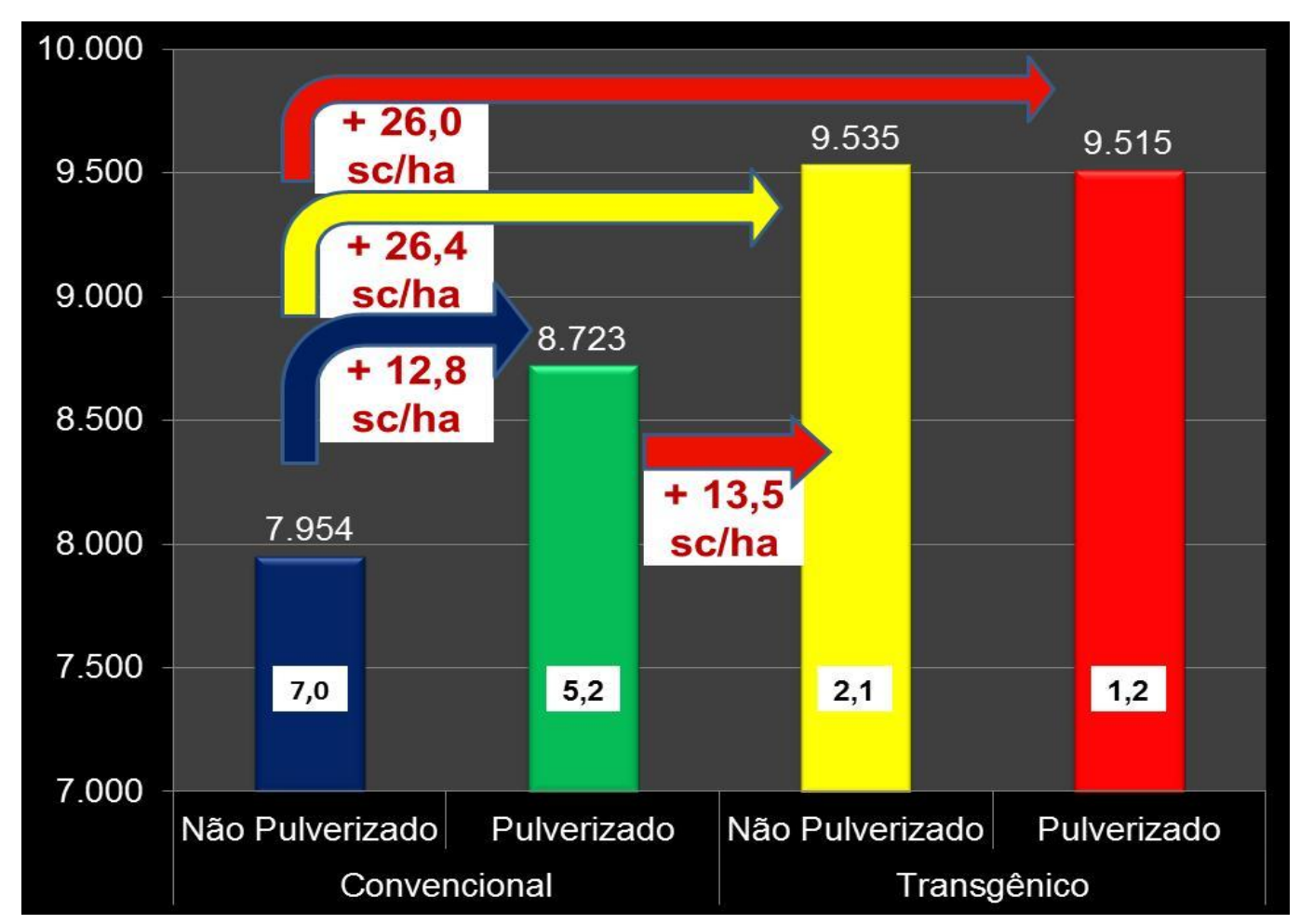

\section{EFEITO DAS TECNOLOGIAS BT NAS PRAGAS NÃO ALVO}

Apesar do conhecimento de que os materiais $B t$ 's apresentam controle somente sobre as lagartas, alguns produtores ao adquirirem sementes de híbridos transgênicos, acreditam estar livres da utilização de inseticidas no milho. No entanto, outros insetos vêm atingindo o status de pragas, devido às praticas agrícolas adotadas, como a sucessão de milho nos plantios da safra e safrinha, ou milho após plantio de soja, como é o caso dos insetos sugadores.

Nos últimos anos tem sido frequente a queixa de produtores com relação à ocorrência de pulgões, principalmente o pulgão-do-milho, Rhopalosiphum maidis (Hemiptera: Aphididae), que possui coloração do corpo verde-escura e pernas pretas. Sua alta infestação está muito associada ao clima seco. Esta característica, combinada com altas temperaturas, beneficia o rápido desenvolvimento e dispersão deste inseto. Os indivíduos alados, responsáveis pela dispersão, se alojam no cartucho formando novas colônias que se desenvolvem no pendão em formação e estas só são visualizadas no estádio de pendoamento, quando a população já está bem alta e, muitas vezes, a produção afetada. Outro fator que pode ter contribuído para o aumento expressivo desses insetos em cultivos de milho é a utilização de milho $B t$ em função da redução do número de pulverizações para o controle da lagarta-do-cartucho, Spodoptera frugiperda, realizado por alguns inseticidas que possuíam algum efeito sobre os pulgões, controlando-o indiretamente.

Outra praga que vem aumentando sua importância na cultura do milho é o percevejo barrigaverde, D. melacanthus (Heteroptera: Pentatomidae) há muito tempo tem causado algum prejuízo na cultura da soja. 
Ao atacarem as plântulas de milho, na região do caulículo, causam pequenas perfurações e à medida que o milho cresce e as folhas se desenvolvem, as lesões aumentam, formando áreas necrosadas no sentido transversal da folha, podendo esta dobrar na região danificada (Figura 16). Como resultado do dano, as plantas de milho ficam com o desenvolvimento comprometido, apresentando um aspecto popularmente chamado de "encharutamento" ou "enrosetamento", com amarelecimento das folhas que prejudicam o desenvolvimento normal das plantas, ocasionando também o perfilhamento exagerado. Em ataques severos ocorre morte das plantas com consequente redução no estande, podendo ocasionar perdas de até $25 \%$ da produtividade.

Segundo Slansky Júnior e Panizzi (apud SLANSKY; RODRIGUEZ, 1987), os danos nos tecidos vegetais são resultantes da penetração dos estiletes e duração da alimentação, associados a secreções salivares pré-digestivas tóxicas e causar necrose tecidual. Além das lesões nas folhas sintomas mais intensos são deformações das plantas podendo levá-las a morte e/ou intenso perfilhamento que originam perfilhos totalmente improdutivos.

Uma dos fatores que tem contribuído para o aumento de importância na cultura do milho é o uso do sistema de plantio direto que preconiza o não revolvimento do solo e manutenção da palhada. Segundo Carvalho (2007), ninfas e adultos são encontrados sobre o solo, próximos à base das plantas ou sob os restos culturais da soja, o qual fornece abrigo e alimento, resultando em crescimento populacional.

Outro fator que pode ter contribuído para o aumento expressivo desses insetos em cultivos de milho foi a liberação de híbridos de milho geneticamente modificados (Bt) no Brasil, onde o uso desta tecnologia propicia a redução do número de pulverizações para o controle da lagarta-do-cartucho, Spodoptera frugiperda, realizado por alguns inseticidas que possuíam algum efeito sobre os percevejos, controlando-o indiretamente.

Figura 16. Adultos de Dichelops melacanthus alimentando-se na base de plântulas de milho (A) e lesões causadas no tecido vegetal em função da alimentação (B).

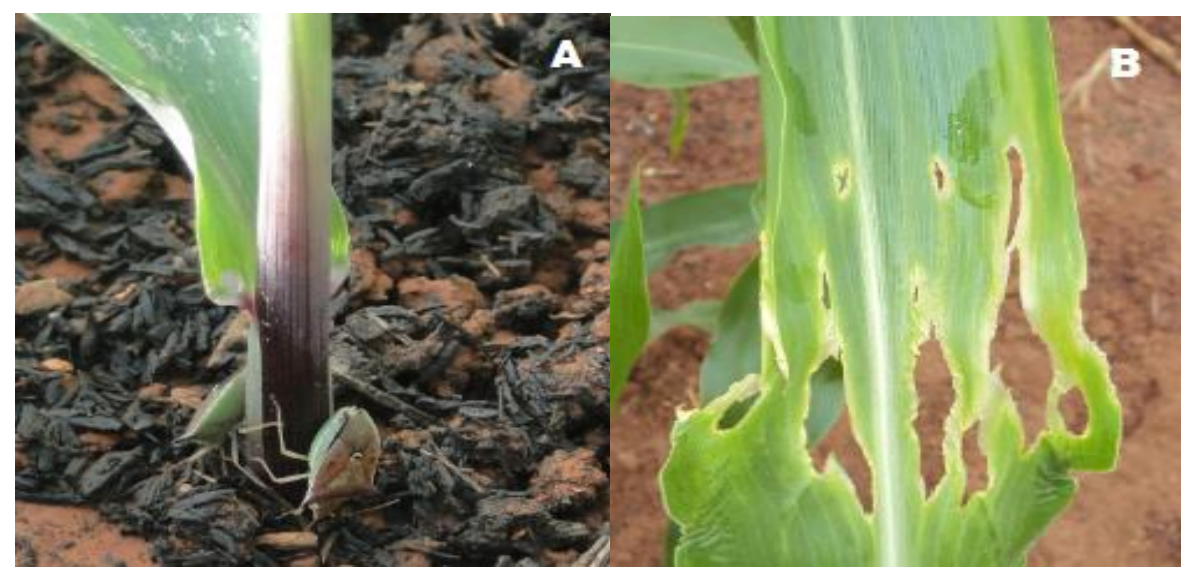

Em trabalho realizado recentemente em parceria entre a Apta Regional Centro Norte de Pindorama e a FCAV/Unesp de Jaboticabal, ambas do Estado de São Paulo, objetivou-se avaliar os danos ocasionados por este percevejo em plantas de diferentes híbridos comerciais convencionais e transgênicos de milho, submetidos previamente ou não ao tratamento químico de sementes. Para garantir a presença do percevejo, as plantas foram infestadas artificialmente na densidade de um inseto adulto por planta (CROSARIOL NETTO et al., 2012a,b).

Para a porcentagem de plantas com sintomas de ataque do percevejo não foram observadas diferenças significativas entre os híbridos (Figura 17), no entanto, nota-se que de modo geral todos os 
híbridos transgênicos tiveram menor porcentagem de ataque do que suas isolinhas convencionais com exceção do par de híbridos IMPACTO/IMPACTO TL, onde o transgênico teve maior porcentagem de ataque. A alta porcentagem de plantas com sintomas de ataque em todos os híbridos pode ser explicada pela alta infestação.

Figura 17. Porcentagem de plantas com sintomas de ataque do percevejo barriga-verde em híbridos de milho convencionais e transgênicos. Pindorama, SP. 2010/2011.

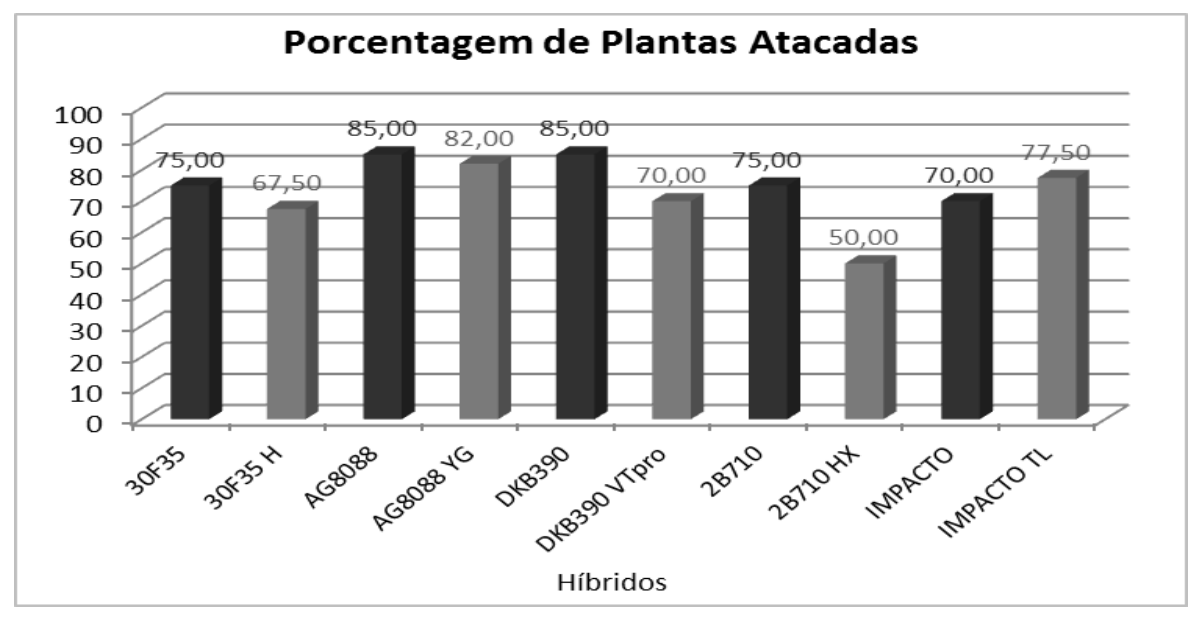

Quando as sementes dos híbridos de milho foram previamente tratadas com inseticida, observouse que a percentagem de plantas atacadas foi significativamente menor (Figura 18).

Figura 18. Porcentagem de plantas com sintomas de ataque do percevejo barriga-verde oriundas de sementes tratadas e não tradadas previamente com inseticida. Pindorama, SP. 2010/2011. * inseticida tiametoxam.

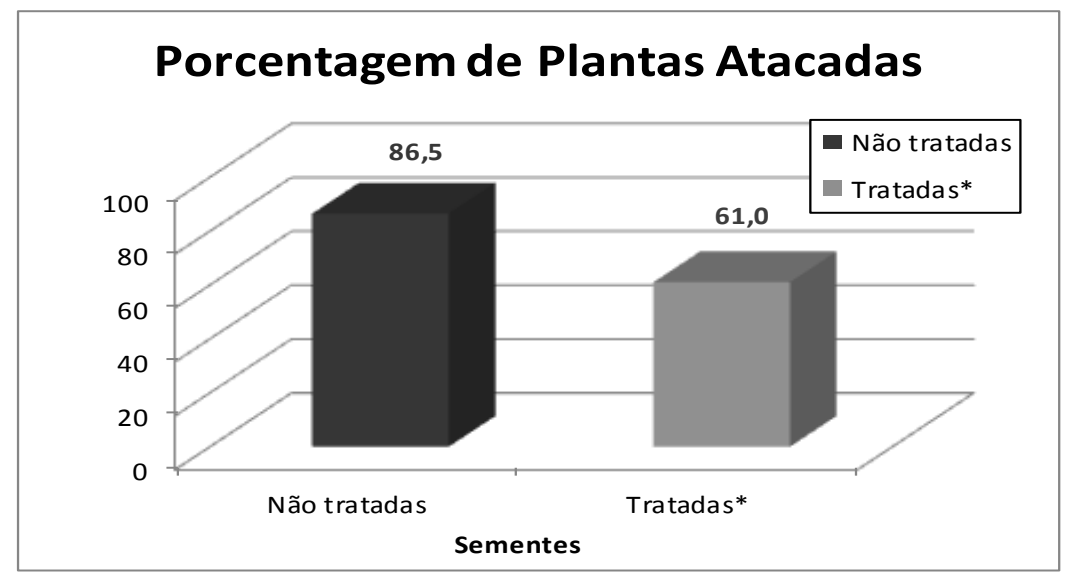

Outro parâmetro avaliado foi a altura das plantas, desde a emergência até o início do pendoamento. Observou-se em todas as avaliações que, plantas submetidas ao tratamento químico de sementes apresentaram em média maior altura em relação às plantas cujas sementes não foram tratadas com tiametoxam, mostrando de fato que o tratamento de sementes contribui para a menor percentagem de plantas atacas, menor sintoma de ataque e consequentemente maior desenvolvimento inicial das plantas.

Quando se analisou a influencia dos híbridos e a redução na altura das plantas em função da não utilização do tratamento de sementes, observou-se que em alguns híbridos não houve diferença entre convencionais e transgênicos, exemplo 30F35 e 30F35H; DKB390 e DKB390 VTpro. Já nos híbridos IMPACTO e IMPACTO TL, AG8088 e AG8088YG e principalmente 2B710 e 2B710HX, houve uma 
redução de altura significativamente maior nos híbridos convencionais. Quando comparado à redução média de altura dos híbridos convencionais com os transgênicos, observou-se que os híbridos convencionais tiveram em média $33,7 \%$ de redução na altura contra 17,8\% dos híbridos transgênicos, muito pelo fato da diferença entre os híbridos 2B710 e 2B710HX.

Com relação aos componentes de produtividade das plantas não foram observados diferenças significativas entre os híbridos avaliados, exceto para o número de fileiras de grãos/espiga, na qual o híbrido 2B710HX apresentou maior número de fileiras, enquanto que o híbrido DKB390 VTpro apresentou o menor número. Porém para o fator correspondente ao tratamento químico de sementes, observou-se diferença significativa em todos os parâmetros avaliados, na qual as plantas oriundas de sementes submetidas ao tratamento químico com tiametoxam apresentaram melhor desempenho de produtividade em relação às plantas oriundas de sementes não submetidas ao tratamento (Tabela 3). Observou-se nesta situação em que estava presente um inseto por planta uma redução média de aproximadamente $30 \%$ na produção de grãos/planta quando não se utilizou o tratamento de sementes (Tabela 3).

$\mathrm{Na}$ análise realizada para verificar o efeito do ataque do percevejo nas variáveis de produtividade entre os híbridos convencionais e suas respectivas isolinhas transgênicas, não se observaram diferenças significativas (Tabela 4), ou seja, apesar dos híbridos transgênicos terem apresentado desempenho superior em relação aos convencionais, isto não refletiu na melhora dos componentes de produtividade, conforme observado na Tabela 4.

Os resultados obtidos até o momento demonstram que o percevejo barriga-verde ao se alimentar de plântulas de milho, causa efeitos negativos às plantas, como diminuição da altura e nos componentes de produtividade. Os híbridos convencionais e transgênicos respondem de forma diferente ao ataque do percevejo, sendo os híbridos convencionais os mais prejudicados num primeiro momento, mas não a ponto de interferir na produtividade.

Tabela 3. Efeito do ataque do percevejo barriga-verde no peso de espiga (g) com e sem palha, peso de grãos por planta (g) e número de fileira de grãos por espiga. Pindorama, SP. 2010/2011.

(Continua)

\begin{tabular}{|c|c|c|c|c|}
\hline \multirow{2}{*}{ Híbridos (H) } & \multicolumn{2}{|c|}{ Peso de espiga (g) } & \multirow{2}{*}{$\begin{array}{c}\text { Peso de } \\
\text { Grãos/Planta } \\
\text { (g) } \\
\end{array}$} & \multirow{2}{*}{$\begin{array}{l}\mathrm{N}^{0} \text { de Fileira de } \\
\text { Grãos/espiga }\end{array}$} \\
\hline & Com palha & Sem palha & & \\
\hline 30F35 & 210,9 & 187,6 & 150,3 & $14,8 \mathrm{ab}$ \\
\hline 30F35 H & 168,5 & 147,8 & 116,9 & $13,4 \mathrm{ab}$ \\
\hline AG8088 & 181,1 & 161,2 & 130,1 & $13,1 \mathrm{ab}$ \\
\hline AG8088 YG & 177,7 & 156,3 & 125,6 & $14,2 \mathrm{ab}$ \\
\hline DKB390 & 162,0 & 147,9 & 121,6 & $14,0 \mathrm{ab}$ \\
\hline DKB390 VTpro & 156,8 & 139,4 & 115,9 & $13,0 \quad b$ \\
\hline $2 B 710$ & 148,1 & 130,6 & 100,6 & $13,2 \mathrm{ab}$ \\
\hline 2B710 HX & 221,8 & 203,9 & 154,8 & $16,9 \mathrm{a}$ \\
\hline IMPACTO & 185,5 & 174,8 & 127,1 & $15,7 \mathrm{ab}$ \\
\hline IMPACTO TL & 175,1 & 154,3 & 119,9 & $15,4 \mathrm{ab}$ \\
\hline
\end{tabular}


Tabela 3. Efeito do ataque do percevejo barriga-verde no peso de espiga (g) com e sem palha, peso de grãos por planta (g) e número de fileira de grãos por espiga. Pindorama, SP. 2010/2011.

(Conclusão)

\begin{tabular}{|c|c|c|c|c|}
\hline Média & 178,7 & 160,4 & 126,3 & 14,4 \\
\hline Teste $\mathrm{F}(\mathrm{H})$ & $1,87^{\mathrm{ns}}$ & $1,97^{\mathrm{ns}}$ & $1,65^{\mathrm{ns}}$ & $2,21 *$ \\
\hline \multicolumn{5}{|l|}{ Trat. Sem (TS) } \\
\hline Não tratadas & $149,0 \quad b$ & $133,9 \mathrm{~b}$ & $104,4 \quad b$ & $13,2 \mathrm{~b}$ \\
\hline Tratadas & $208,5 \mathrm{a}$ & $186,8 \mathrm{a}$ & $148,2 \mathrm{a}$ & $15,6 \mathrm{a}$ \\
\hline Teste F (TS) & $31,27 * *$ & $27,41 * *$ & $30,68 * *$ & $18,51 * *$ \\
\hline \multicolumn{5}{|l|}{ Interação } \\
\hline Teste F (H x TS) & $0,70^{\mathrm{ns}}$ & $0,79^{\mathrm{ns}}$ & $0,55^{\mathrm{ns}}$ & $0,96^{\mathrm{ns}}$ \\
\hline $\mathrm{CV}(\%)$ & 26,64 & 28,2 & 27,99 & 17,32 \\
\hline
\end{tabular}

Médias seguidas pela mesma letra na coluna não diferem entre si a 5\% de probabilidade pelo teste de Tukey. ns não significativo a 5\% de probabilidade pelo teste de Tukey.

**, *; Significativo a 1 e $5 \%$ de probabilidade pelo teste $\mathrm{F}$.

Tabela 4. Efeito do ataque do percevejo barriga-verde na massa de espiga (g) com e sem palha, massa de por planta $(\mathrm{g})$ e número de fileira de grãos por espiga. Em isolinhas convencionais e transgênicas Pindorama, SP. 2010/2011.

\begin{tabular}{|c|c|c|c|c|}
\hline \multirow{2}{*}{ Híbridos } & \multicolumn{2}{|c|}{ Peso de Espiga (g) } & \multirow{2}{*}{$\begin{array}{c}\mathbf{N}^{0} \text { Fileira de } \\
\text { Grãos/Espiga (g) }\end{array}$} & \multirow{2}{*}{$\begin{array}{c}\text { Peso de } \\
\text { Grãos/Planta } \\
\text { (g) }\end{array}$} \\
\hline & Com palha & Sem palha & & \\
\hline Convencionais & 177,5 & 157,9 & 14,2 & 125,9 \\
\hline Transgênicos & 180,0 & 160,3 & 14,6 & 126,6 \\
\hline Teste $\mathbf{F}$ & $0,05^{\mathrm{ns}}$ & $0,06^{\mathrm{ns}}$ & $0,63^{\mathrm{ns}}$ & $0,01^{\mathrm{ns}}$ \\
\hline
\end{tabular}

Médias seguidas pela mesma letra na coluna não diferem entre si a 5\% de probabilidade pelo teste de Tukey. ns - não significativo a $5 \%$ de probabilidade pelo teste de Tukey.

**, *; Significativo a 1 e $5 \%$ de probabilidade pelo teste $\mathrm{F}$.

O que realmente parece ser uma importante ferramenta para o produtor é a utilização de inseticida via tratamento de sementes, pois acarreta diminuição do número de plantas atacadas e diminuição dos danos ocasionados pelo percevejo e proporcionando melhor desenvolvimento das plantas e produtividade de grãos. Outros estudos estão sendo desenvolvidos no intuito de se determinar os reais danos do percevejo em condições de campo e seus reflexos na produtividade.

\section{CONSIDERAÇÕES FINAIS}

São inegáveis os ganhos proporcionados pela adoção de híbridos de milho transgênicos na redução dos danos ocasionados pela lagarta-do-cartucho, lagarta-da-espiga e broca-da-cana. No entanto, esta tecnologia também está em constante desenvolvimento, uma vez que diversos isolados de Bacillus thuringiensis mais eficientes estão sendo selecionados e liberados para comercialização.

Além disso, no plantio de híbridos convencionais, o produtor deve realizar o monitoramento constante da lavoura, para identificar o momento de se realizar o controle das pragas, necessitando assim pessoas treinadas, pulverizador adequado, escolherem um inseticida eficiente e de baixo impacto nos inimigos naturais, contar com condições climáticas ideais de temperatura e umidade, para que seja feito o 
controle da praga com eficiência. Já com a utilização de milho $B t$ de qualidade, com exceção do monitoramento que deve continuar, todas as outras táticas já estão presentes na semente, o que proporciona menores riscos de intoxicação do aplicador e, portanto maior tranquilidade ao produtor.

Importante salientar sobre as áreas de refúgio, uma vez que estas áreas são responsáveis pela fonte de insetos suscetíveis à tecnologia, mantendo a frequência de insetos resistentes baixas e prevenindo o desenvolvimento de populações resistentes no campo e consequentemente mantendo por maior período a eficiência de controle das pragas pela tecnologia $B t$.

\section{REFERÊNCIAS}

CARVALHO, E. S. M. Dichelops melacanthus (Dallas, 1851) (Heteroptera: Pentatomidae) no Sistema Plantio Direto no Sul do Mato Grosso do Sul: Flutuação Populacional, Hospedeiros e Parasitismo. 2007. 57p. Dissertação (Mestrado em Entomologia e Conservação da Biodiversidade) Curso de Pós Graduação em Entomologia e Conservação da Biodiversidade, Universidade Federal de Grande Dourados, Dourados, MS.

CELERES. Relatório Biotecnologia. 4p. <http://celeres.com.br/wordpress/wpcontent/uploads/2012/12/RelBiotecBrasil_1202_por.pdf>. Acesso em 18 mar. 2013.

CROSARIOL NETTO, J.et al. Efeito do ataque de Dichelops melacanthus (Dallas) na produtividade de híbridos comerciais convencionais e transgênicos de milho com e sem tratamento de sementes. In: CONGRESSO BRASILEIRO DE MILHO E SORGO, 29. Anais... 2012, Águas de Lindóia. SP. p.827832, 2012a.

CROSARIOL NETTO, J.et al. Danos ocasionados por Dichelops melacanthus (Dallas) em híbridos convencionais e transgênicos, submetidos ou não ao tratamento de sementes. In: CONGRESSO BRASILEIRO DE MILHO E SORGO, 29. Anais... 2012, Águas de Lindóia. SP. p.820-826, 2012b.

GATTI, J.H. et al. Eficiência de Diferentes Tecnologias Bt no Controle de Pragas na Safrinha: I. Controle da Lagarta-do-Cartucho. In: CONGRESSO BRASILEIRO DE MILHO E SORGO, 29. Anais... 2012, Águas de Lindóia. SP. p.973-978, 2012.

JIMENÉZ-JUÁREZ, N.et al. Bacillus thuringiensis Cry1Ab mutants affecting oligomer formation are non toxic to Manduca sexta larvae. Journal of Biological Chemistry, v.282, p.21222-21229, 2007.

LYNCH, R.E.et al. Management of corn earworm and fall armyworm (Lepidoptera: Noctuidae) injury on a sweet corn hybrid expressing a Cry1A(b) gene. Journal of Economic Entomology, v.92, n.5, p.1217$1222,1999$.

MICHELOTTO, M.D., FREITAS, R.S.; PIROTTA, M.Z.; PEREIRA, A.D.; FINOTO, E.L. Eficiência de Diferentes Tecnologias $B t$ no Controle de Pragas na Safrinha: III. Efeito na Produtividade. In: CONGRESSO BRASILEIRO DE MILHO E SORGO, 29. Anais... 2012, Águas de Lindóia. SP. p.967972, 2012.

MICHELOTTO, M.D.et al. Tecnologia protetora. Revista Cultivar - Grandes Culturas, n.145, p.36-38, 2011.

PIROTTA, M.Z.et al. Eficiência de Diferentes Tecnologias Bt no Controle de Pragas na Safrinha: II. Controle da Broca-da-Cana e de Lagartas na Espiga. Controle da Lagarta-do-Cartucho. In: CONGRESSO BRASILEIRO DE MILHO E SORGO, 29. Anais... 2012, Águas de Lindóia. SP. p.1031-1037, 2012.

SLANSKY JUNIOR R.; PANIZZI, A.R. Nutritional ecology of seedsucking insects. In: SLANSKY, J.R.; RODRIGUEZ, J.G. Nutritional ecology of insects, mites, spiders and related invertebrates. New York: Wiley, 1987. 